\title{
THE TAXATION OF CORPORATE EXCESS PROFITS IN PEACE AND WAR TIMES
}

\author{
Alfred G. Buehlex*
}

Excess profits taxation has been a subject of active discussion since it rose to prominence during the World War. After this form of taxation proved to be spectacularly productive of revenue as a war measure, interest turned to it as a potential peace time tax. The difficulties inherent in the administration of excess profits taxation and its heavy burdens on industry at high rates caused its general abandonment after the war, however, and only a few governments, notably the United States, Japan, and the Irish Free State, have employed it consistently in times of peace. In the United States thought has recently been devoted to the possible development of the excess profits tax as a permanent revenue of importance, although many critics of the tax believe it should be imposed; if at all, only in times of war. With the advent of war again in Europe, a number of bills have been introduced in Congress which would take all profit out of war, or would very largely confiscate war-time profits by taxation. Some would go so far as to have all munitions manufactured by the government.

Congress has, indeed, under the Vinson Act of 1934, endeavored to restrict the profits in contracts for the construction of naval vessels, aircraft, and parts for domestic use involving more than $\$ 10,000$ to $10 \%$ of the sum involved, with the requirement that profits in excess of that percentage shall be taken by the government. Senator Nye has suggested that the rates of all the federal income taxes should be doubled during a war. Senator Bone would levy a tax at a rate of $100 \%$ on corporation profits in excess of $6 \%$ during war times. Various other tax proposals have been introduced in Congress which would be inaugurated as measures of war finance, with the purpose of obtaining revenues from the profits arising during a war boom and also limiting such profits.

Much of the recert thought on the excess profits tax, however, has arisen from its consideration as an ordinary peace time revenue. The economists of the Twentieth Century Fund, in their study of the American tax system, have recommended the repeal of the present makeshift excess profits tax and the substitution for it of a moderate rate tax which would be extended cautiously over a period of years while

- A.B., 1922, Heidelberg College; A.M., 1923, Ph.D., 1930, Yale University. Associate Professar of Public Finance, University of Pennsylvania. Auhor of General. Sales Taxation (1932); Public Finance (1936, 2d ed., 1940); The Undirtxibuted Profits TAx (1937). Contributor to various periodicals. 
the government gathered experience in its administration. ${ }^{1}$ A similar proposal has been advanced by a committee of the National Tax Association. ${ }^{2}$ Various arguments have been presented in defense of the excess profits tax as a normal revenue. It is advocated as a measure which would recognize the so-called ability to pay of corporations more adequately than other profits taxes, as a device to strike at monopolies and regain for society their abnormal profits, as a supplement to price-fixing legislation, and as a stabilizer of business conditions which would tend to check runaway booms and prevent depressions.

Quite recently England, Canada, France, and Germany have again resorted to excess profits taxes, primarily as sources of war revenues. The excess profits tax has thus become a current issue and it is pertinent to inquire with what success it was collected at the time of the World War and thereafter and what promises it may offer as a source of revenue during the days of peace as.well as the crises of war financing.

\section{Excess Profits Taxes During War}

The excess profits taxes during the World War originated as taxes upon the profits of munitions makers and vendors. Then all profits arising from the war directly were taxed. Finally, the excess profits of business in general, whether they were directly or indirectly the by-product of the war, were taxed. That is, the taxes on profits obtained from munitions suggested the taxes on war profits, and, in a short time, the taxes on excess profits. This evolution occurred rather spontaneously among the leading nations as they learned from their mutual experience, and excess profits taxes appeared among the neutrals as well as among the belligerents.

In England the excess profits tax of 1915 was preceded by the munitions profits tax, which limited these profits to $20 \%$ of the average profit of the two preceding years. ${ }^{3}$ In the United States the War Revenue Act of 1916 levied a tax at a rate of $12.5 \%$ upon the profits of munitions manufacturers. The following year Congress imposed a general war profits tax, at rates graduated from 20 to $60 \%$, on all of the profits of corporate and noncorporate enterprise in excess of a return of $8 \%$ of the invested capital, and then replaced this tax with an excess profits tax. In 1918 the excess profits tax was limited to corporations and consolidated with the war profits tax, and the tax rates were graduated up to $80 \%$. Corporations were obliged to pay either the war profits or the excess profits tax, whichever was the larger. Under the 1918 law an exemption of $\$ 3,000$ in profits was allowed. For the excess profits tax a rate of return of $8 \%$ was allowed as normal, and for the war profits tax, 10\%. After the war the rate of the excess profits tax was dropped to $40 \%$. In 1921 the tax was repealed.

The English excess profits tax of 1915 was collected at a rate of $50 \%$ of the profits exceeding by more than $£ 200$ the prewar profits. In 1916 the tax rate was raised to $60 \%$ and in 1917 it was further advanced to $80 \%$. After the war, in 1919, the tax rate

${ }^{2}$ Shour and Others, Factive the Tax Prozlex (1937) 491-494.

2 Report of the Committee on Federal Taxation of Corporations, NAt. TAx Assin, Proceedings, 1939.

* For an account and an analysis of the Englistr excess profits tax, see Haig and Holmes, The Taxation of Excess Profits in Greas Britain (1920) 10 Alc. Ecos. REv., Supp. 
was lowered to $40 \%$. In 1920 it was returned to $60 \%$. In 1921 the tax expired. As a basis for calculating the standard prewar profits the taxpayer ordinarily averaged the profits of any two of the last three years before the war. Where the prewar profits were abnormally depressed, the taxpayer could select the average of any four of the last six years preceding the war.

The American method of determining excess profits taxation was essentially that of valuing capital investments in order to ascertain the existence of a rate of profits in excess of what was arbitrarily set as a normal rate of return. Under the British plan excess profits were essentially the profits in excess of the prewar profits, rather than the rate of the prewar profits. England offered an alternative, however, of a tax to be related to the rate of the return on the investment if this would lower the tax on the total amount of excess profits. Under the IgI7 law the taxpayer was allowed to employ a return of $6 \%$, if he were incorporated, and $8 \%$ if he were not incorporated, in those cases where prewar profits were unusually low.

\section{REVENUES From WAR TAXES}

The war-time excess profits taxes were notably productive of revenues. In the United States the excess profits tax became the source of more revenue than any other tax, and in 1918 provided over $\$ 2,500,000,000$, in conjunction with the war profits tax. After the war the receipts declined, as Table $I$ indicates.

TABLB I

American War and Excess Profits Tax Receipts.

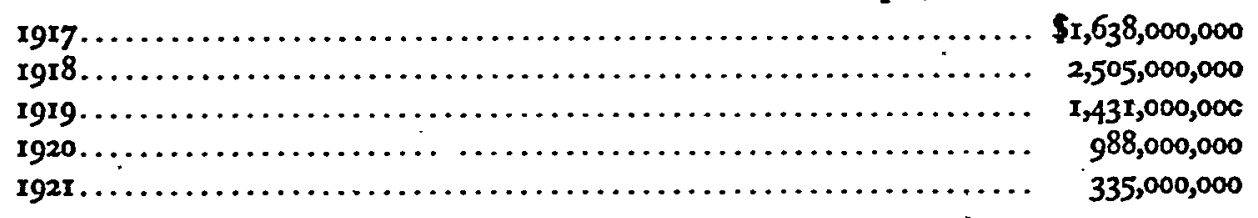

In Great Britain the excess profits tax also supplied amazingly large revenues. In 1918-IgIg the collections from this tax exceeded the receipts from any other tax. In the next year a maximum of $£_{2} 89,000,000$ was obtained from the excess profits tax, as shown in Table $20^{\circ}$

\section{TABLs 2}

\section{British Excess Profits Tax Revenues}

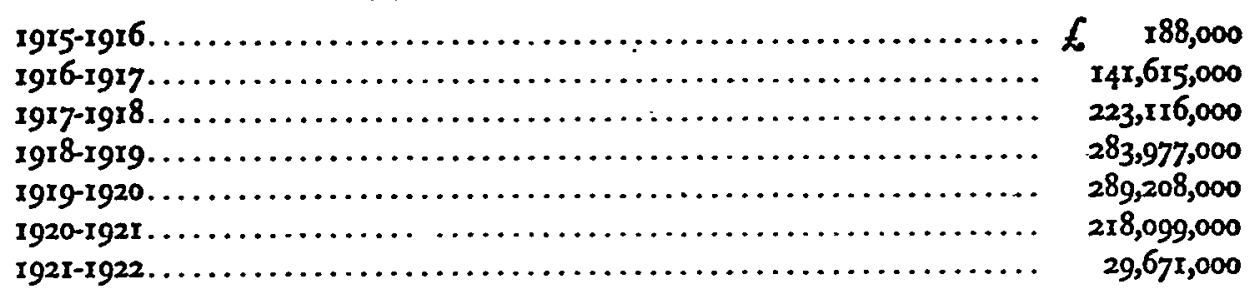

-Hearings before the Senate Finance Committee on the Revenue Act of 1935, 74th Cong., Ist Sest. (1935) 22.

- Report of the Commitsee on National Debt and Taxation, Cmd., 2800 (1927) 73. 


\section{Role of Excess Profits Tax In War Times}

The World War experience with excess profits taxation in many countries demonstrates the tremendous receipts which may be obtained from the revenue during periods of war prosperity and inflation. The taxes arose in response to the demand to take over for the government a large part of the profits which resulted directly or indirectly from the war. During the crisis when man power was conscripted for the war it was quite universally agreed that capital would also be drafted and profiteering should be limited by price controls and by taxation. The American and British excess profits taxes were cheerfully paid during the war, for the most part, and evasion and avoidance tended to be limited by the desire to help the government win the war with patriotic support.

When the war ceased, the excess profits taxes, which had previously been such promising revenues, rapidly disintegrated. In the depression that followed the war profits declined and tax payments slumped. The excess profits taxes had been regarded as emergency taxes which would expire at the close of the war, and their high rates, inequalities in burdens, and administrative complications contributed to their downfall. Once the war was over the game of beating the government by tax evasion and avoidance began in earnest on a rather large scale. In both England and the United States the excess profits taxes were found to encourage wasteful and otherwise questionable expenditures by the taxpayers in their efforts to spend their profits rather than be taxed upon them. Excessive capitalization occurred as profits were plowed back into enterprises in order to increase the capitalization and reduce the rate of return compared with the invesiment.

In the United States business enterprises united in vigorous condemnation of the continuance of the excess profits tax, which also lost its revenue potency as profits were transformed into losses during the postwar deflation. Many persons blamed the excess profits tax for the high prices which prevailed during the war, although the tax, as a general proposition, was apparently not shifted to consumers but was paid out of the surpluses which arose during the war boom. When the excess profits tax was adopted Secretary of the Treasury McAdoo praised it as a revenue device. After the tax had been in operation for a few years the succeeding Secretaries of the Treasury joined the cther critics of the tax, which was said to be highly complex in its administration, a factor operating agajnst conservative financial management because of its encouragement of overcapitalization, a tax with highly unequal burdens, and, in general, a tax with unhealthful effects upon business enterprise.

Because of its unpopularity the excess profits tax was abandoned in country after country, in spite of the efforts of many persons to have the tax revamped for use as a peace-time revenue. Much of the ill will which was directed against the excess profits tax after the war undoubtedly was an expression of opposition to its high rates, which were suddenly imposed upon the business community and were felt to be highly

\footnotetext{
'See Sec'y of tre Treas., Ans. Report 1918, pp. 46-47; id., 1919, pp. 23-24; id., 1920, pp. 32, 38-39; id., 1921, pp. 9, 21.
} 
restrictive after the cessation of hostilities. Governments were willing to relinquish their war profits taxes because of their unpopularity, their administrative complexities, and their declining revenues. The claims for refunds after the war, when losses were heavy, also acted to convince governments that a revenue which may be very productive during war prosperity may be a disappointment during the postwar depression.

The excess profits tax has generally been commended as a tax which is warranted in war times because of the huge revenues it may provide. Those who have condemned it as a peace tax have commonly conceded its propriety as a temporary expedient in war time, when its administrative difficulties and its inequalities and undesirable effects are of secondary importance. During the World War the tax was collected without seriously disturbing national economic organizations, and if may apparently be carried during war and similar booms without grave effects upon business enterprise. It is therefore not to be marveled at that the excess profits tax has been revived during the present European war. In this war it may again be the source of large tax revenues.

The German law of March 20, 1939 introduced a surtax of $30 \%$ on the excess of income in 1938 over 1937 in order to reach the profies being obtained in the armament and construction industries? The tax was adopted at a time when Germany was at peace, but it must be considered in relation to her military program. The tax was . also applied to personal incornes in excess of 3,000 marl-s. Exemptions were granted to agriculture and forestry and to individual enterprises where it was considered nocessary to reinvest profits to finance plant expansion. Immediately numerous protests were registered against the heavy burden of the new surtax, and on April 26 , 1939 the tax rate was reduced to $15 \%$ and the exemption of incomes was raised to include incomes not over 7,200 marks. Taxpayers were also allowed to substitute the year 1935 for 1937 as the basis for determining normal income.

France was not slow in taking action in 1939, even before the outbreak of the war with Germany, in limiting the profits which might be obtained frcm war contracts. A decree of April 21, 1939 imposed a tax ranging from a rate of $50 \%$ on profits of from 6 to $10 \%$ on government contracts up to a rate of $100 \%$ on profits in excess of $20 \%$. A decree of September 1, 1939 placed a tax of $25 \%$ on profits from armaments and other sources in excess of $2 \%$ of the capital invested and a tax of $100 \%$ or profits in excess of $8 \%$.

England also adopted an excess. profits tax shortly before she declared war on Germany. The law of July 28, I939 levied an armament profits duty upon concerns with profits from armaments in excess of $£ 200,000$. This law was soon superseded by the law establishing an excess profits tax at a rate of $60 \%$ on all business profits, corporate and noncorporate, in excess of the standard profits. The carned income of individuals and partnerships is exempt, but their profits are taxable. The valuation of the capital investment is regulated by rather complex rules. The valuation, in

'The writer is indebted to the Division of Commercial Laws, U. S. Department of Commerce, for dat concerning recent foreign excess profits azer. 
general, shall not be larger than an amount which would permit a return of $6 \%$ on the investment. The standard profits may be the profits of a certain year, or they may be an average of two years, depending upon the date the business was organized. England has also continued her national defense contribution, or $2 \operatorname{tax}$ of $5 \%$ on corporation profits and $4 \%$ on the profits of individual proprietors and partners. The taxpayer is liable for the excess profits tax or the national defense contribution, whichever is the larger.

The Dominion of Canada may also be mentioned as one of the nations which have recently revived the excess profits tax. Under the 9939 law Canada imposed a tax increasing from a rate of $10 \%$ on the profits of business enterprise in excess of $5 \%$ and not over $10 \%$ of the capital invested up to a rate of $60 \%$ on the profits in excess of $25 \%$ of the investment. The excess profits taxes recently adopted by the belligerents in the European war are to be attributed indirectly, if not directly, to it The lessons of the World War have not been forgotten, and a tax which earlier was highly productive is again being developed. It seems probable that if ine United States should become a belligerent in the European or another war some form of excess profits taxation wouid immediately be resorted to, not only to raise revenue but also to limit the profits to br, made from the conflict.

\section{The. Excess Profits Tax IN Peace Times}

The discussion thus far has dealt with the excess profils tax as a measure of war finance. It has been employed in a number of countries as a peace-time revenue, however, including the United States, where the federal government employs a socalled excess profits tax as a supplement to the capital stock tax. For a number of years Japan has employed an excess profits tax which, as in other countries, is paid in addition to the normal profits taxes. In 1937 the tax rates ranged from $4 \%$ on profits from to to $20 \%$ of the invested capital up to $20 \%$ of the profits in excess of $30 \%$ of the invested capital. In the Irish Free State, as in Japan, the excess profits tax has been utilized as a normal revenue. The collections of the tax in the $2930^{\circ}$ fluctuated between $f_{120,000}$ and $\oint_{240,000}$. The Irish tax has been a quite minor revenue. Excess profits taxes have also been employed by other nations during times of peace. Colombia adopted such a tax in 1934 and Mexico in 1939.

For the American student the federal tax on so-called excess profits is of considerable interest. It was revived along with the capital stock tax on corporations in r933 and, like the capital stock tax, it is collected only from corporations. Profits are deemed to be excessive when the rate of the return on the adjusted declared value of the capital stock is in excess of $10 \%$. The tax rates are $6 \%$ on the profits over 10 per cent and not over $15 \%$ of the value of the stock and $12 \%$ on the profits in excess of $15 \%$ of the value of the stock. During the World War the capital stock tax supplied relatively small revenues in comparison with the highly productive excess profits tax, but the situation is now reversed, as Table 3 shoprs. In 1939 the excess 
profits tax returned only $\$ 27,000,000$ while the capital stock tax was the source of \$127,000,000."

Taxix 3

Revenues from Federal Excess Profits and Capital Stock Taxes

\begin{tabular}{|c|c|c|}
\hline Year & Excess profits tax & Capital stock tax \\
\hline $\begin{array}{l}193 \\
193\end{array}$ & $\begin{array}{r}\ldots 2,630,000 \\
\ldots \quad 6,560,000\end{array}$ & $\begin{array}{r}80,168,000 \\
91,508,000\end{array}$ \\
\hline 1936. & ... 14,509,000 & $94,943,000$ \\
\hline $\begin{array}{l}1937 . \\
1938 .\end{array}$ & $\begin{array}{l}\text {.. 25,105,000 } \\
\ldots 36,569,000\end{array}$ & $\begin{array}{l}137,499,000 \\
\times 39,349,000\end{array}$ \\
\hline 1939. & .. 27,056,000 & $127,203,000$ \\
\hline
\end{tabular}

In the recent revival of excess profits taxation corporations were allowed to set any value they wished upon their capital investment, but the original value was to remain unchanged except as capital was placed into or taken out of the enterprise. The tax was adopted as a piecautionary measure to assure the payment of the capital stock tax by corporations, which would otherwise be tempted to coclare a low value for their invested capital in order to reduce their capital stock tax. In case this were done, however, the corporation might find itself liable for an excess profits tax, which would not have been paid if a higher value had been placed upon the capital stock.

As new revenue laws were adopted, contrary to the original plan, corporations were allowed to readjust the declared value of their capital stock. Under the r939 law, in order to allow corporations to reduce their excess profits taxes because of inaccurate profit forecasts, they may declare a higher value upon their capital stock for 1939 and $194^{\circ}$. For the year ending June 30, $194^{\circ}$ and every third year thereafter, corporations may adjust the valuation of their capital stock either upward or downward. The government found that corporations were unable to forecast profits three years ahead, and rather than force them to wait until r94r, as the $193^{8}$ law would have required, they were permitted to revise their valuation upward in 1939.

Since only a fraction of our business corporations earn excess profits as a rule, the threatened liability of the great majority of corporations for the excess profits tax if they avoid their capital stock taxes is only an idle gesture unless their capital valuations are highly erroneous. The method of valuation emphasizes estimated net carnings and does not give an accurate statement of the amount of capital placed in an enterprise and subsequent changes in its value. The government recognizes the colossal obstacles which would arise in the attempted valuation of the investments of hundreds of thousands of corporations and has not seriously endeavored to obtain an accurate valuation of those investments.

As early as 5936 Treasury officials admitted that "great administrative difficulties" are encountered in the endeaver to enforce an excess profits tax effoctively." In $193^{8}$

- Sec'y of the Treastat, ANA. Repost, 1939, p. 375.

- See the statements of Conmissioner of Internal Revenue Guy T. Helvering and General Counsel Herman Oliphant, Hewings before the Ilouse Ways and Meens Committee on the Revenue Aet of 2936 , 74th Cong, 2d Sas. (1936) 24, 606. 
the then Undersecretary of the Treasury, Mr. Roswell Magill, declared, in speaking of the excess profits and capital stock taxes, "These two taxes have little to recommend them save the assurance of one hundred and fifty to one hundred and seventyfive million dollars of revenue. ... The capital stock tax does not require the actual evaluation of the corporation assets nor is the excess profits tax a true tax upon the excess of earnings over a reasonable return on the capital invested. ${ }^{\text {n10 }}$ The Secretary of the Treasury, in 1939, was moved to apply the label of "tax irritants" to the excess profits and capital stock taxes. He affirmed, "The taxes are thus not really taxes on the value of capital stock or on excessive profits. Their major defect is that they operate very erratically. The tax liability they impose depends on the taxpayer's ability to forecast profits for the next three years as well as upon the amount of profits actually realized during each of the three years."

The censuring of the excess profits and capital stock taxes by the Treasury offcials has been mild as compared with the less restrained criticism directed against them by accountants and business executives. The repeal of both taxes has often been urged by accountants. The Committee on Federal Taxation of the American Institute of Public Accountants has repeatedly urged the repeal of these taxes because they are considered unsound and based upon valuations which are obtained by guess work. ${ }^{12}$ Many economists would undoubtedly agree that the present capital stock and excess profits taxes are inequitable in their application and that their only defeuse is that they produce certain minor revenues. Afuch is to be said for their repeal and the use of more equitable taxation to supply the deficiency of revenue which would result.

\section{Theory of Excess Proftrs Taxation}

In an appraisal of the excess profits tax as a revenue it will be desirable to examine more critically the theory upon which the tax may rest and a few of the grave prob. lems which are encountered in its use. As a war measure the excess profits tax has generally been accepted by business enterprise and by economists because of its great productivity and in spite of its unequal burdens and administrative complications. Active disagreement exists, however, over the role which the tax should play in times of peace.

The ability-to-pay theories of taxation have often been advanced in justification of excess profits taxation as a normal revenue. Business enterprises do not, however, possess ability to pay taxes in any personal sense and.can only be said to have an impersonal capacity to pay taxes. All of the owners of a corporation do not have equivalent incomes, wealth, and financial obligations. Any tax upon corporation profits which reaches all the owners of a business at the same rate cannot be adjusted

${ }^{10}$ Hearings before the House Ways and Means Committee on Revision of Revienue Laws, 1939, 75th Cong., 3d Sess. (1938) 105.

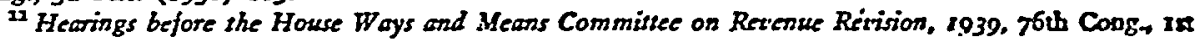
Sess. ( 1939$) 5-6$.

1s The report of the Committee was printed in (1939) 68 J. of Accotrrraxcx 312. 
to their various abilities to pay taxes. Economists have therefore looked upon the excess profits tax as a business, and not a personal, tax.

If the rates of return upon business investments could be determined accurately and if averages of the rates of return over a period of several years were employed, then a tax based upon these averages would, from a number of angles, be more equitable than other forms of profits taxation. Such a tax would not be merely an excess profits tax, although it would tax the higher profits ratios at higher rates than the lower profits ratios. It would be a general business profits tax and should, from the economic standpoint, be applied to noncorporate as well as to corporate profits.

Numerous statistical studies have shown that the rates of return upon business investments are highly variable among individual establishments and industries. ${ }^{18}$ Among the successful corporations reporting net income it is generally true that the smaller corporations earn a higher rate of return than the larger corporations. It is also true that the profits of the smaller successful corporations are more variable than the profits of the larger corporations reporting net income. The shorter the time period employed for determining excess profits, the more will a tax upon them penalize the smaller enterprises and the risky undertakings with highly fluctuating earnings. If a long enough period is taken, the development of new enterprises and the growth of young businesses will not suffer from tax discrimination. Ideally an excess profits tax should be adapted to the particular profit and capital conditions of each enterprise because of the great variability in earning capacities which prevails.

The assumption that high rates of return upon investments are evidence of persistent monopoly control over prices may be questioned in view of the fact that high profit ratios are often found among young and small enterprises which may have a high rate of return one year and losses the next. If the excess profits tax is employed to reach monopoly profits of an excessive nature, it must be based upon the average profits of a period of years if it is not to discourage ventures which may encounter losses as readily as profits. The application of an excess profits tax to high monopoly profits is one of the most appealing arguments for the use of this tax in times of peace as well as in times of war. Where governmental price control is ineffective or impracticable, an excess profits tax might be employed successfully to draw considerable revenues from the surplus profits of monopolies.

The excess profits tax has also been proposed as a vehicle for putting the brakes. upon business expansion during boom periods which may generate a crisis and eventual depression. To be effective as a business stabilizer, an excess profits tax would apparently have to be a flexible measure which could be adapted to variable business conditions. If improperly employed the tax might unduly check business expansion. ${ }^{14}$

\footnotetext{
2s As excellent recent analysis of the rates of return on corporate investments will be found in CRuM, Corporate Size and Earning Power (I939).

14 For further discussion of the use of taxation to stabilize business, see Buesring, Pususe Finarick (2d ed., 1940) 674-680.
} 


\section{The Valuation of Bosiness Investagents}

Probably the most serious obstacle to the utilization of the excess profits tax as a normal peace-time revenue is the administrative problem of defining accurately the excess profits of business enterprises. The advantages of an excess profits tax are appealing and at first thought it may seem easy to determine the existence of excess profits. To avoid the necessity of evaluating business investments an excess profits tax may; as has sometimes been done, be based upon the excess of total profits in the taxable year over the total profits of a given base year or the average of total profits in two or more selected years. It is next to impossible, however, to find a normal year or period for this type of excess profits taxation which will not result in grave inequalities unless the tax is adjusted by the administration to the particular conditions of each establishment. Allowances must be made for capital additions and withdrawals, for business expansion and contraction. The total profits, of course, do not indicate the rate of profit return. It is highly significant that the present excess profits tax of England defines excess profits in relation to the value of the investment rather than in terms of prewar or standard total profits. The opinion prevailed in England after the World War that considerations of equity require a valuation of investments in order that the rates of return upon them may be discovered. ${ }^{15}$ Economists appear to be agreed that it is more logical to employ a tax based upon the rate of the return rather than a tax based upon the excess of profits over those in a given period.

The valuation of investments, however, is a colossal undertaking and it is questionable if such valuation is reasonably practicable. The valuation of public utilities for rate-making and the valuation of property for taxation suggest some of the crucial problems which would arise in valuation for excess profits taxation. It is true, of course, that the federal income tax administration was still in its infancy at the time of the World War and that the experience gained from nearly three decades of income tax administration should be very helpful in developing the administration of a suitable excess profits tax.

The present excess profits tax is such a weak substitute for an adequate tax that the government would have to start out practically anew if it were to grapple with the inherent and baffing problems of this form of taxation. The Treasury has shown no eagerness to attemipt to administer a real excess profits tax, and has, in fact, dis- . played a willingness to abandon the present tax as soon as its revenues can be replaced. The argument that normal profits do not really exist hecause profits are essentially variable may be met by arbitrarily setting a rate of return which is regarded as normal, but the far more difficult problem of valuing business investments cannot be waved aside by similar perfunctory action.

\footnotetext{
${ }^{28}$ Note the discussion of the British excess profits tax in Haig and Holmes, supra note 3 , at $164,173$.
} 